\title{
Catalytic Effect of Inorganic Elements on Steam Gasification Biochar Properties from Agrowastes
}

\author{
Lina María Romero Millán, ${ }^{*}, \dagger \odot$ Fabio Emiro Sierra Vargas, ${ }^{\dagger}$ and Ange Nzihou ${ }^{\ddagger}$ \\ ${ }^{\dagger}$ Universidad Nacional de Colombia, Sede Bogotá, Facultad de Ingeniería, Ciudad Universitaria, Bogotá, Colombia \\ ${ }^{\ddagger}$ Université de Toulouse, Mines Albi, CNRS, Centre RAPSODEE, Campus Jarlard, Route de Teillet, F.81013 Albi, Cedex 09, France
}

\begin{abstract}
Steam gasification chars from lignocellulosic agrowastes are highly microporous materials with specific surface areas between 500 and $1000 \mathrm{~m}^{2} / \mathrm{g}$, comparable to that of activated carbons. Nevertheless, the analysis and comparison of gasification chars from different feedstocks revealed the important effect of the raw biomass inorganic composition on their physicochemical properties. In particular, it was found that the catalytic effect of alkali and alkaline earth metals (AAEM) on the steam gasification reactions resulted in higher char specific surface areas, with greater proportions of surface oxygen-containing functional groups. In contrast, this effect was not observed for Si and P rich samples. In accordance, the biomass inorganic ratio $\mathrm{K} /(\mathrm{Si}+\mathrm{P})$ proved to be a valuable indicator of the steam gasification char reactivity, giving a new insight for the engineering of useful value-added materials from lignocellulosic agrowastes. The mechanisms presented in this work could be an important reference for real gasification applications working with different kind of residues when the valorization of the solid byproduct is targeted.
\end{abstract}

\section{INTRODUCTION}

Tropical regions have a great potential for the development of agricultural and agroindustrial activities thanks to their climate and geographic location. Generally, developing countries in these areas base their economy in agriculture and related activities, producing great amounts of agrowastes that usually remain under-exploited. These residues could be valorized as biofuels to meet local energy needs in rural and isolated areas, considering that several communities still lack access to reliable energy services. However, in most cases, the sustainability of valorization projects depends on the creation of related productive activities that go beyond the energy supply, generating new incomes for local communities. ${ }^{1,2}$ In this regard, simultaneous energy and business development opportunities around agrowastes valorization should be considered.

In this context, steam gasification is an interesting thermochemical process, as it produces high heating value fuel gases that can be used for heat or power generation ${ }^{3,4}$ and a porous carbon-based byproduct, also called char, that could be valorized. ${ }^{5,6}$ Nevertheless, as the availability of agrowastes is often seasonal, gasification facilities should work with different kind of residues that have diverse characteristics. In this regard, the understanding of the impact of the feedstock characteristics on the gasification behavior and byproducts is of great importance to properly adapt the process conditions to the application requirements.

The influence of the process parameters on the char properties has been widely analyzed for several lignocellulosic agrowastes. The gasification temperature and time, as well as the reaction atmosphere, are reported to have a very important impact on the char characteristics. ${ }^{7,8}$ Among these parameters, the reaction atmosphere has probably the most important effect on the char porous structure and surface chemistry. ${ }^{9-12}$ In particular, steam gasification chars are comparable to physically activated carbons, with high surface areas and pore volumes and an important amount of surface functional groups. ${ }^{13,14}$ In contrast, air gasification chars usually need to be upgraded by subsequent activation to be used in adsorption or catalytic applications. ${ }^{10-12}$

In this regard, the impact of the feedstock characteristics on the properties of the gasification chars still needs to be investigated. Different authors have suggested that the macromolecular composition and the ash content of the samples may have an influence on the properties of activated carbons and chars. ${ }^{15-17}$ However, as most studies deal with only one kind of feedstock, the understanding of this question needs to be improved.

Previous works have proven that the composition of the samples impacts their gasification reactivity in an important way. ${ }^{18,19}$ In particular, the inorganic content of the biomass could play a catalytic or an inhibitory role in the progress of the steam gasification reactions. More specifically, alkali and alkaline earth metals (AAEM) like $\mathrm{K}, \mathrm{Ca}, \mathrm{Na}$, and $\mathrm{Mg}$ have a beneficial effect on biomass gasification, ${ }^{20,21}$ which could be inhibited by elements like $\mathrm{Al}, \mathrm{Si}$, and $\mathrm{P}$. Nevertheless, the influence of inorganics in the gasification char properties is not clear.

In this work, the influence of the raw biomass characteristics and composition on the physicochemical properties of steam gasification chars is analyzed. Coconut shells (CS), bamboo guadua (BG), and oil palm shells (OPS) were selected as feedstocks, considering their different macromolecular structure and inorganic composition. The evaluation and comparison of the surface area, pore structure, and surface chemistry of chars revealed the important impact of the indigenous 
Table 1. Organic and Inorganic Composition of the Raw Biomasses ${ }^{a}$

\begin{tabular}{|c|c|c|c|c|}
\hline & & CS & BG & OPS \\
\hline \multirow[t]{5}{*}{ elemental analysis (wt \% daf) } & $\mathrm{C}$ & $46.8 \pm 0.2$ & $42.7 \pm 0.3$ & $46.7 \pm 0.2$ \\
\hline & $\mathrm{H}$ & $5.8 \pm 0.1$ & $5.4 \pm 0.1$ & $6.5 \pm 0.1$ \\
\hline & $\mathrm{O}^{*}$ & $47.1 \pm 0.1$ & $51.5 \pm 0.1$ & $46.2 \pm 0.1$ \\
\hline & $\mathrm{N}$ & $0.3 \pm 0.1$ & $0.4 \pm 0.1$ & $0.6 \pm 0.1$ \\
\hline & ash & $1.4 \pm 0.1$ & $5.0 \pm 0.4$ & $1.7 \pm 0.2$ \\
\hline \multirow[t]{8}{*}{ inorganic composition ( $\mathrm{mg} \mathrm{kg}^{-1}$ dry biomass) } & $\mathrm{Al}$ & $261.6 \pm 8$ & $243.4 \pm 3$ & $1500.0 \pm 2$ \\
\hline & $\mathrm{Ca}$ & $391.4 \pm 7$ & $441.3 \pm 9$ & $53.8 \pm 6$ \\
\hline & $\mathrm{Fe}$ & $159.8 \pm 2$ & $116.0 \pm 1$ & $107.4 \pm 4$ \\
\hline & $\mathrm{K}$ & $2807.8 \pm 4$ & $5360.1 \pm 8$ & $1006.5 \pm 15$ \\
\hline & $\mathrm{Mg}$ & $170.4 \pm 15$ & $172.7 \pm 1$ & $135.2 \pm 3$ \\
\hline & $\mathrm{Na}$ & $330 \pm 1$ & $200 \pm 0.8$ & $15 \pm 0.5$ \\
\hline & $\mathrm{P}$ & $396.7 \pm 4$ & $828.6 \pm 6$ & $270.0 \pm 7$ \\
\hline & $\mathrm{Si}$ & $309.3 \pm 4$ & $19372.1 \pm 354$ & $5600.0 \pm 3$ \\
\hline \multirow[t]{3}{*}{ molecular composition (wt \% daf) } & cellulose & 32.5 & 53.9 & 30.4 \\
\hline & hemicellulose & 20.5 & 13.5 & 12.7 \\
\hline & lignin & 36.5 & 25.1 & 49.8 \\
\hline
\end{tabular}

inorganic elements on the gasification reactivity and the resulting structure and chemistry of chars.

\section{MATERIALS AND METHODS}

2.1. Materials. The chars obtained from the steam gasification of oil palm shells (OPS), coconut shells (CS), and bamboo guadua (BG) were characterized and analyzed in this study. The chemical organic and inorganic composition of the raw materials were determined according to the standards of solid biofuels, detailed in a previous work, ${ }^{18,22}$ and are summarized in Table 1.

2.2. Gasification Experimental Setup. Steam gasification experiments were carried out in a semi continuous lab-scale fluidized bed gasifier. The reactor, with $60 \mathrm{~cm}$ height and $6 \mathrm{~cm}$ of internal diameter, is made of stainless steel and is externally heated using electrical resistances. A porous disk at the bottom of the reactor holds the biomass sample and allows the gasification atmosphere to pass through. The nitrogen gas flow supplied to the process is regulated by a calibrated mass flow controller. For its part, steam is supplied by a steam generator equipped with a water mass flow controller and a heating device producing superheated steam at $180{ }^{\circ} \mathrm{C}$.

For all the experiments, $80 \mathrm{~g}$ of ground biomass (particle size between 2 and $4 \mathrm{~mm}$ ) were placed inside the reactor and heated to the gasification temperature $\left(750\right.$ or $\left.850{ }^{\circ} \mathrm{C}\right)$ at a heating rate of 20 ${ }^{\circ} \mathrm{C} / \mathrm{min}$ under nitrogen. When the gasification temperature was reached, the atmosphere was switched to a mixture of $\mathrm{H}_{2} \mathrm{O} / \mathrm{N}_{2}$ (from $15 \%$ to $90 \%$ of steam in the gasifying agent, 50 to $300 \mathrm{~g} / \mathrm{h}$ of steam) and was maintained during all the gasification stage ( $t$ from 1 to $3 \mathrm{~h}$ ). The total flow rate was $0.7 \mathrm{~m}^{3} / \mathrm{h}$ for all the experiments. After each test, the reactor was cooled to room temperature under nitrogen. The remaining char was collected, weighted, and stored for subsequent characterization. Pyrolysis-only tests were performed to determine the solid yield at the end of the heating period (pyrolysis stage) for each gasification temperature. To verify reproducibility, tests were carried out twice. The repeatability was found to be satisfactory as the standard deviation of the solid yield was below $3 \%$.

2.3. Char Burn-off and Gasification Reactivity. For each steam gasification test, the char burn-off achieved at the end of the experiment was calculated according to eq 1 :

$$
\text { burn-off }(\%)=\frac{m_{0}-m_{\mathrm{f}}}{m_{0}} \times 100
$$

where $m_{0}$ is the mass of the sample at the beginning of the gasification stage, determined from the pyrolysis-only tests, and $m_{\mathrm{f}}$ is the mass of the remaining char at the end of the experiment, on a dry ash free basis.
Likewise, from the measurement of the remaining char at the end of each gasification experiment, the average gasification reactivity of the samples can be calculated for different gasification times. The degree of conversion of the char after the gasification stage is defined as in eq 2:

$$
\alpha(t)=\frac{m_{0}-m(t)}{m_{0}-m_{\mathrm{ash}}}
$$

where $m_{0}$ is the mass of the sample at the beginning of the gasification stage, $m(\mathrm{t})$ the mass at the end of the gasification period $t$, and $m_{\text {ash }}$ the mass of ash in the sample.

The apparent gasification reactivity can be then defined as a function of the conversion degree $\alpha$, as presented in eq 3. Generally, reactivity comparisons are referred to a specific char conversion level. However, as the continuous monitoring of the mass loss of each biomass is not possible for the presented experimental setup, the gasification reactivity is presented in this study as an average for a defined gasification time and is calculated according to eq 4 , where $t$ is the time of the steam gasification stage, from 1 to $3 \mathrm{~h}$.

$$
\begin{aligned}
& R(\alpha)_{(\mathrm{app})}=\frac{1}{1-\alpha(t)} \frac{\mathrm{d} \alpha}{\mathrm{d} t} \\
& R(\alpha)_{(\text {app)average }}=\frac{1}{n} \sum_{t=1}^{n} \frac{1}{1-\alpha(t)} \frac{\mathrm{d} \alpha}{\mathrm{d} t}
\end{aligned}
$$

2.4. Char Characterization. 2.4.1. Proximate Analysis and Elemental Composition. The elemental analysis (CHNS) of the collected chars was determined using a Thermoquest NA 2000 elemental analyzer. To determine their inorganic composition, 150 $\mathrm{mg}$ of ground char (with a particle size below $500 \mu \mathrm{m}$ ) was acid digested in closed vessels at $220{ }^{\circ} \mathrm{C}$ during $4 \mathrm{~h}$. Acid reagents $\mathrm{H}_{2} \mathrm{O}_{2}$, $\mathrm{HNO}_{3}, \mathrm{HF}$, and $\mathrm{H}_{3} \mathrm{BO}_{3}$ were used according to EN 16967. Acid solutions were diluted with demineralized water to $50 \mathrm{~mL}$ and analyzed using an HORIBA Jobin Yvol Ultima 2 inductively coupled plasma-optical emission spectrometer (ICP-OES). For its part, the ash content of the samples was calculated according to EN ISO 18122. All analyses were performed with at least three replicates.

2.4.2. Scanning Electron Microscopy (SEM) and Transmission Electron Microscopy (TEM). The morphology of the chars was observed using a Hitachi TM3030 Plus tabletop scanning electron microscope with an accelerating voltage of $15 \mathrm{kV}$. The local chemical composition at a microscale was determined by using the energy dispersive X-ray spectroscopy (EDX) module in the same apparatus. For its part, elemental mapping of chemical species in the samples was also performed using a JEOL JEM-ARM200F transmission electron microscope with an integrated EDX module. 
Table 2. Organic and Inorganic Composition of the Analyzed Chars

\begin{tabular}{|c|c|c|c|c|c|c|c|c|c|c|}
\hline \multirow[b]{2}{*}{ sample } & \multicolumn{5}{|c|}{ elemental analysis (wt \% dry basis) } & \multicolumn{5}{|c|}{ main inorganic constituents ( $\mathrm{mg} \mathrm{kg}^{-1}$ dry basis) } \\
\hline & $\mathrm{C}$ & $\mathrm{H}$ & $\mathrm{N}$ & $\mathrm{O}^{a}$ & Ash & $\mathrm{Ca}$ & $\mathrm{K}$ & $\mathrm{Na}$ & $\mathrm{P}$ & $\mathrm{Si}$ \\
\hline $\mathrm{CS} \_30 \% \_750{ }^{\circ} \mathrm{C} \_1 \mathrm{~h}$ & 87.7 & 1.3 & 0.3 & 6.8 & 3.9 & 390.0 & 8146.6 & 3130.0 & 242.7 & 1398.5 \\
\hline CS_90\%_750 ${ }^{\circ} \mathrm{C} \_1 \mathrm{~h}$ & 84.6 & 1.4 & 0.3 & 9.2 & 4.5 & 205.7 & 12330.8 & 4010.0 & 495.1 & 1887.0 \\
\hline CS_30\%_750 ${ }^{\circ} \mathrm{C} \_2 \mathrm{~h}$ & 81.1 & 1.4 & 0.2 & 9.6 & 7.7 & 910.2 & 10518.6 & 3050.0 & 141.7 & 1012.5 \\
\hline CS_30\%_750 ${ }^{\circ} \mathrm{C} \_3 \mathrm{~h}$ & 82.3 & 1.5 & 0.2 & 10.0 & 6.0 & 497.1 & 19495.8 & 4580.8 & 358.1 & 1222.1 \\
\hline $\mathrm{CS} \_30 \% \_850{ }^{\circ} \mathrm{C} \_1 \mathrm{~h}$ & 79.2 & 1.3 & 0.0 & 11.3 & 8.2 & 387.7 & 20393.8 & 4188.7 & 274.0 & 954.6 \\
\hline $\mathrm{CS} \_30 \% \_850{ }^{\circ} \mathrm{C} \_2 \mathrm{~h}$ & 80.7 & 1.2 & 0.1 & 10.9 & 7.1 & 381.4 & 16845.7 & 4102.0 & 305.4 & 1695.5 \\
\hline $\mathrm{BG} \_30 \% \_750{ }^{\circ} \mathrm{C} \_1 \mathrm{~h}$ & 69.7 & 1.2 & 0.3 & 5.2 & 23.6 & 984.2 & 15438.4 & 432.7 & 804.4 & 56563.7 \\
\hline BG_90\%_750 ${ }^{\circ} \mathrm{C} \_1 \mathrm{~h}$ & 68.5 & 1.1 & 0.4 & 6.8 & 23.2 & 850.8 & 22200.1 & 554.9 & 1124.2 & 81173.2 \\
\hline BG_30\%_750 ${ }^{\circ} \mathrm{C} \_2 \mathrm{~h}$ & 67.1 & 1.0 & 0.2 & 7.2 & 24.5 & 1281.0 & 21991.1 & 447.8 & 884.9 & 73697.0 \\
\hline BG_30\%_750 ${ }^{\circ} \mathrm{C} \_3 \mathrm{~h}$ & 67.6 & 1.0 & 0.2 & 6.5 & 24.8 & 1127.8 & 22397.8 & 427.8 & 925.8 & 77031.0 \\
\hline BG_30\%_850 ${ }^{\circ} \mathrm{C} \_1 \mathrm{~h}$ & 60.8 & 0.8 & 0.3 & 6.6 & 31.5 & 1004.3 & 30168.7 & 376.5 & 2627.8 & 72091.0 \\
\hline BG_30\%_850 ${ }^{\circ} \mathrm{C} \_2 \mathrm{~h}$ & 49.1 & 0.6 & 0.1 & 6.2 & 44.0 & 670.9 & 64937.1 & 525.9 & 5786.5 & 96860.0 \\
\hline BG_30\%_850 ${ }^{\circ} \mathrm{C} \_3 \mathrm{~h}$ & 36.7 & 0.6 & 0.1 & 4.8 & 57.9 & 880.3 & 84258.2 & 603.1 & 8563.0 & 120697.0 \\
\hline OPS_30\%_750 ${ }^{\circ} \mathrm{C} \_1 \mathrm{~h}$ & 87.0 & 1.3 & 0.7 & 6.6 & 4.4 & 1234.2 & 3984.6 & 35.4 & 1304.2 & 12623.1 \\
\hline OPS_90\%_750 ${ }^{\circ} \mathrm{C} \_1 \mathrm{~h}$ & 84.9 & 1.4 & 0.6 & 7.7 & 5.5 & 1500.8 & 4201.2 & 41.3 & 1443.4 & 13052.2 \\
\hline OPS_30\%_750 ${ }^{\circ} \mathrm{C} \_2 \mathrm{~h}$ & 87.5 & 1.3 & 0.5 & 6.0 & 4.6 & 1425.8 & 4003.1 & 51.3 & 1305.5 & 13906.2 \\
\hline OPS_30\%_750 ${ }^{\circ} \mathrm{C} \_3 \mathrm{~h}$ & 87.6 & 1.3 & 0.5 & 5.8 & 4.8 & 1506.3 & 4512.3 & 61.2 & 1654.8 & 13748.2 \\
\hline OPS_30\%_850 ${ }^{\circ} \mathrm{C} \_1 \mathrm{~h}$ & 85.2 & 0.8 & 0.5 & 8.6 & 4.9 & 1555.9 & 7290.8 & 54.6 & 2155.8 & 14945.5 \\
\hline OPS_30\%_850 ${ }^{\circ} \mathrm{C} \_2 \mathrm{~h}$ & 83.8 & 0.8 & 0.4 & 9.3 & 5.6 & 1651.3 & 7425.8 & 101.1 & 2187.3 & 15624.1 \\
\hline OPS_30\%_850 ${ }^{\circ} \mathrm{C} \_3 \mathrm{~h}$ & 81.0 & 0.8 & 0.3 & 9.6 & 8.3 & 1589.4 & 8495.6 & 90.2 & 2874.2 & 16879.0 \\
\hline
\end{tabular}

2.4.3. Char Pore Structure and Specific Surface Area. The pore structure of gasification chars was determined by nitrogen adsorption at $77 \mathrm{~K}$ using a Micromeritics 3Flex high-resolution analyzer. Prior to measurements, the samples were degassed in vacuum at $90{ }^{\circ} \mathrm{C}$ during $1 \mathrm{~h}$ and then at $150{ }^{\circ} \mathrm{C}$ during $10 \mathrm{~h}$. The surface area was calculated from the adsorption isotherms using the Brunauer-Emmett-Teller (BET) model. The $t$-plot model was used to determine the micropore volume of the samples.

2.4.4. Surface Oxygen-Containing Functional Groups (SOFG). The oxygen-containing functional groups in the char surface were determined using temperature-programmed desorption (TPD) analysis. Experiments were carried out in a Micromeritics AutoChem II chemisorption analyzer. First, $150 \mathrm{mg}$ of char was placed in a quartz U-tube and heated under a helium atmosphere. The sample was kept at $150{ }^{\circ} \mathrm{C}$ for $1 \mathrm{~h}$ and then was heated to $1000{ }^{\circ} \mathrm{C}$ with a heating rate of $5{ }^{\circ} \mathrm{C} / \mathrm{min}$. The concentration of $\mathrm{CO}$ and $\mathrm{CO}_{2}$ released was quantitatively analyzed using a MyGC Agilent micro-GC. The repeatability of the TPD tests was found to be satisfactory with a maximum calculated standard deviation below $10 \%$.

The obtained $\mathrm{CO}$ and $\mathrm{CO}_{2}$ desorption curves were deconvoluted to determine the contribution of each type of oxygen complex. The procedure used in this work is based on the TPD spectra analysis proposed by Zhou et al. ${ }^{23}$ using six Gaussian peaks for the deconvolution of the $\mathrm{CO}$ desorption curve and six peaks for the $\mathrm{CO}_{2}$ curve. Regarding the peak assignment, it has been generally stated that the $\mathrm{CO}_{2}$ desorption at low temperatures is associated to carboxylic acids, while lactones decomposition results in $\mathrm{CO}_{2}$ desorption at high temperatures. Also, carboxylic anhydrides decomposition is related to both $\mathrm{CO}$ and $\mathrm{CO}_{2}$, while phenols, ethers, and quinones result in $\mathrm{CO}$ desorption. ${ }^{24}$ Despite these trends, different authors have demonstrated that desorption temperatures of SOFG can vary with the heating rate and with their chemical and geometric local environment. Consequently, it may be difficult to clearly determine the content of each particular functional group from TPD patterns. However, it is possible to quantify the global CO and $\mathrm{CO}_{2}$ yielding groups and estimate their proportion in the char surface.

Accordingly, the $\mathrm{CO}_{2}$ desorption curves obtained were decomposed using Gaussian functions centered at $250 \pm 50{ }^{\circ} \mathrm{C}$ and $380 \pm$ $50{ }^{\circ} \mathrm{C}$ for carboxylic groups, $500 \pm 50{ }^{\circ} \mathrm{C}$ for peroxydes, and $620 \pm$ $50{ }^{\circ} \mathrm{C}, 750 \pm 50{ }^{\circ} \mathrm{C}$, and $800 \pm 50{ }^{\circ} \mathrm{C}$ for lactones at different energetic sites. In the same way, the $\mathrm{CO}$ curves were deconvoluted using functions centered at $400 \pm 50{ }^{\circ} \mathrm{C}$ for acid anhydrides, $620 \pm$ $50{ }^{\circ} \mathrm{C}$ for hydroxyl groups, $740 \pm 50{ }^{\circ} \mathrm{C}$ for phenol groups, $860 \pm 50$ ${ }^{\circ} \mathrm{C}$ for ether groups, and $900 \pm 50{ }^{\circ} \mathrm{C}$ and $970 \pm 50{ }^{\circ} \mathrm{C}$ for quinone and pyrone groups, respectively. A constraint over the peak width (55 $\pm 5{ }^{\circ} \mathrm{C}$ ) was used for the optimization of the curve fitting. The fitting error found between the experimental and the deconvoluted curve was always below $8 \%$.

2.4.5. $\mathrm{pH}$ at the Point of Zero-Charge $\left(\mathrm{pH}_{P Z \mathrm{C}}\right)$. The $\mathrm{pH}$ at which the electrical charge density on the char surface is zero $\left(\mathrm{pH}_{\mathrm{PZC}}\right)$ was measured using a Malvern Pananalytical Zetasizer NanoZS. Char samples were ground into powder with a particle size below $250 \mu \mathrm{m}$. About $15 \mathrm{mg}$ of sample was used for each test with an approximate sample concentration of $0.5 \mathrm{mg} / \mathrm{mL}$. Measurements were taken at room temperature within the $\mathrm{pH}$ range from 2 to 11 , adjusted by the addition of a $0.25 \mathrm{M} \mathrm{HCl}$ or $0.1 \mathrm{M} \mathrm{NaOH}$ solution.

\section{RESULTS AND DISCUSSION}

3.1. Composition of Gasification Chars. During experimental tests, the steam fraction in the gasification agent $\left(\mathrm{H}_{2} \mathrm{O} / \mathrm{N}_{2}\right)$ was modified from $15 \%$ to $90 \%$. However, considering that the gasification process analysis showed that a steam fraction near $30 \%$ is associated with the highest process efficiency values, the analysis and comparison of steam gasification chars from the selected precursors will be focused in chars produced with a $30 \%$ steam fraction. Gasification chars obtained using a $90 \%$ steam fraction are also presented for comparison purposes.

In this regard, Table 2 reports the elemental composition of the gasification chars analyzed in the present study. It can be observed that CS and OPS gasification chars are highly carbonaceous materials with a carbon content above $80 \%$. For their part, BG chars, with a higher ash content, exhibit lower carbon percentages from $70 \%$ to $36 \%$.

The mineral composition of gasification chars is in accordance with the analyzed raw biomasses. As observed in Table 2, the main inorganic constituents of CS chars are $\mathrm{K}, \mathrm{Ca}$, and $\mathrm{Na}$, considering that raw $\mathrm{CS}$ contains non-negligible amounts of these elements. In the same way, BG and OPS 

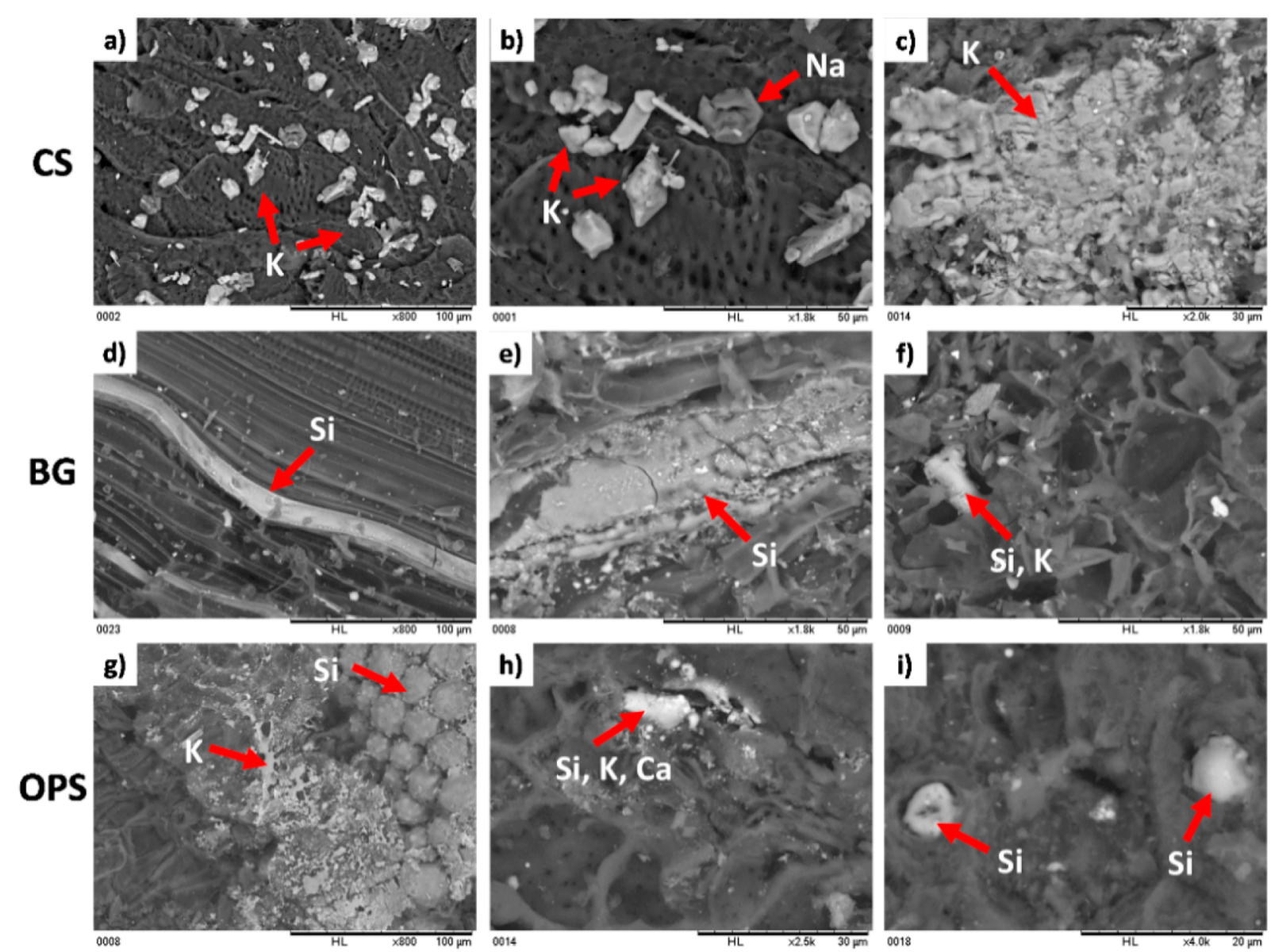

Figure 1. SEM-EDX micrographs of analyzed chars. Gasification conditions: $1 \mathrm{~h}, 850{ }^{\circ} \mathrm{C}, 30 \%$ steam in the gasifying agent.
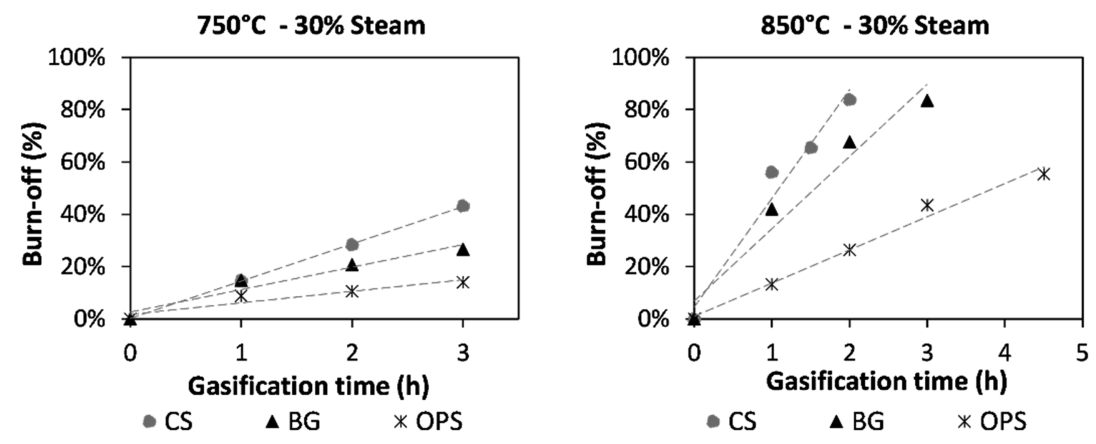

Figure 2. Char burn-off vs gasification time of analyzed samples.

chars show great amounts of $\mathrm{Si}$, taking into account that this is the main inorganic constituent of the original samples. Considering that a certain amount of minerals may volatilize during the gasification process, ${ }^{25,26}$ the observed mineral retention level of the analyzed chars with respect to the raw biomass is between $20 \%$ and $90 \%$. In general, higher temperatures and longer gasification times are related to lower mineral retention percentages, in accordance with the higher solid conversion levels reached at the end of the gasification process.

The dispersion of minerals in the char surface are presented in the SEM-EDX micrographs in Figure 1 for $1 \mathrm{~h}$ gasification chars obtained at $850{ }^{\circ} \mathrm{C}$ with $30 \%$ of steam in the gasifying agent. SEM-EDX images are in agreement with the information obtained from the ICP-OES results and show that minerals in the CS chars are well dispersed in the surface. In general, $\mathrm{K}$ and $\mathrm{Na}$ were the dominant elements detected, with some traces of $\mathrm{Ca}$. Furthermore, $\mathrm{Si}$ was the main element observed in OPS chars, as well as some Ca and K. Finally, SEM-EDX analyses confirmed the higher mineral content of BG chars. In this case, $\mathrm{Si}$ was detected in almost all of the char surface, probably as $\mathrm{SiO}_{2}$ or associated with $\mathrm{K}$.

3.2. Char Yield and Burn-off. For the three feedstocks, the recovered char at the end of the gasification process was reduced with the increase of the steam fraction in the gasifying agent, the temperature, and the gasification time. The impact of these parameters on the gasification behavior of CS, BG, and OPS was analyzed in a previous work at a thermogravimetric scale $^{18}$ and is in accordance with the results obtained in this study. More specifically, higher gasification temperatures and 
steam quantities are related to higher reactivities and then to higher carbon conversions and lower char yields. In the same way, longer gasification times also allow higher carbon conversions, resulting in less recovered char at the end of the experiment.

In general, the impact of the process parameters on the solid yield and burn-off is the same for the three studied biomasses. However, for the same experimental conditions, the calculated char burn-off is always considerably higher for CS in comparison to BG and OPS, as observed in Figure 2.

This behavior is supported by the results of the calculated average steam gasification reactivity of the samples, summarized in Table 3. It is worth noting that these values are in

Table 3. Calculated Mean Gasification Reactivity during $3 \mathrm{~h}$ in a $30 \%$ Steam Atmosphere

\begin{tabular}{cccc} 
& \multicolumn{3}{c}{ mean reactivity $(\% / \mathrm{min})$} \\
\cline { 2 - 4 } temperature & $\mathrm{CS}$ & $\mathrm{BG}$ & OPS \\
$750{ }^{\circ} \mathrm{C}$ & 0.35 & 0.25 & 0.08 \\
$850^{\circ} \mathrm{C}$ & 2.28 & 1.18 & 0.32 \\
\hline
\end{tabular}

accordance with the results obtained at a thermogravimetric scale and presented in a previous work for the same feedstocks. ${ }^{18}$ In fact, regardless of the gasification temperature, the average reactivity values calculated for CS were always higher compared to those for BG and OPS. For instance, at $850{ }^{\circ} \mathrm{C}$, the BG and OPS reactivities correspond to only $51 \%$ and $14 \%$ of the CS value, respectively, explaining the lower solid yield and higher char burn-off observed for CS under the same experimental conditions.

Despite the differences on the macromolecular composition of the selected biomasses, it was possible to identify from the experimental results that the main factor influencing the steam gasification reactivity of lignocellulosic samples is their inorganic composition. In particular, the CS main inorganic constituents are $\mathrm{K}$ and $\mathrm{Ca}$, which are reported to have a catalytic impact on the steam gasification reactions, ${ }^{27-29}$ while OPS and BG are mainly composed of Si and P, which tend to react with AAEM and inhibit their beneficial effect. ${ }^{30,31}$
Accordingly, considering that $\mathrm{K}$ has been reported to have the most important impact on steam gasification reactivity among $\mathrm{AAEM},{ }^{20,31,32}$ the inorganic ratio $\mathrm{K} /(\mathrm{Si}+\mathrm{P})$ was employed in this work to analyze and compare the effect of inorganic composition on the properties of the biomass gasification carbon-based solid byproduct. ${ }^{18,19,33}$ CS with an inorganic ratio of $3.9(\mathrm{~K} /(\mathrm{Si}+\mathrm{P})>1)$ has a higher proportion of $\mathrm{K}$ in relation to $\mathrm{Si}$ and $\mathrm{P}$ and follows a catalytic gasification behavior. In contrast, BG and OPS with inorganic ratios of 0.2 and 0.17 , respectively, $(\mathrm{K} /(\mathrm{Si}+\mathrm{P})<1)$ have a higher proportion of $\mathrm{Si}$ and $\mathrm{P}$ that inhibit the beneficial impact of AAEM (principally K), explaining the differences observed between the char burn-off evolution of CS in comparison to BG and OPS. In agreement with this, the TEM-EDX cartography analysis of BG gasification char is presented in Figure 3. It is possible to observe that elements like $\mathrm{K}$ and $\mathrm{Ca}$, with potential catalytic impact on steam gasification, may be associated with $\mathrm{Si}$, supporting the observed low gasification reactivity of this sample despite its relatively high $\mathrm{K}$ content.

3.3. Char Specific Surface Area and Pore Structure. From the $\mathrm{N}_{2}$ adsorption experiments, it was possible to notice that for the analyzed samples, an increase in the BrunauerEmmett-Teller surface area $\left(S_{\mathrm{BET}}\right)$ was observed with the char burn-off. In fact, the progress of gasification reactions is related to the consumption of carbon atoms with the subsequent formation of pores in the char structure. ${ }^{34}$ This is the basis of the production of activated carbon through physical activation with steam, attributed mainly to Reaction R1:

$$
\mathrm{C}+\mathrm{H}_{2} \mathrm{O} \rightarrow \mathrm{CO}+\mathrm{H}_{2}
$$

In this regard, for the three feedstocks a linear increase in the $S_{\text {BET }}$ was observed with the char burn-off for values below $60 \%$, as presented in Figure 4. The maximum surface areas attained were $1041.8 \mathrm{~m}^{2} / \mathrm{g}$ for CS, $1014.0 \mathrm{~m}^{2} / \mathrm{g}$ for OPS, and 807.7 $\mathrm{m}^{2} / \mathrm{g}$ for BG, comparable to physically activated carbons. ${ }^{35-37}$ The subsequent decline may be due to the weakening and collapse of the char structure due to the progress of the gasification reactions. $^{38,39}$

For burn-off degrees below 30\%, CS chars developed nearly $35 \%$ more surface area compared to BG and OPS chars. In contrast, above $30 \%$, the OPS surface area approached the CS


Figure 3. TEM-EDX cartographic images of BG char. Conditions: $1 \mathrm{~h}$ gasification, $850{ }^{\circ} \mathrm{C}, 30 \%$ steam in the gasifying agent. 




Figure 4. $S_{\mathrm{BET}}$ of gasification chars in relation to burn-off.

char values. The behavior observed at low burn-off degrees may be attributed to the differences in the gasification reactivity of the samples, while the results obtained for higher burn-off degrees could be related to the raw biomass structure and the ash content of chars. In particular, the high ash content of BG chars (higher than 30\%) may explain the lower surface area development in comparison to CS and OPS for burn-off degrees above $30 \%{ }^{40}$

Nevertheless, it is worth mentioning that due to the differences in the gasification reactivity of the samples, the burn-off degree attained is not the same under identical experimental conditions, and then, the developed char surface area is also different. From Table 4, it can be observed that the CS char $S_{\mathrm{BET}}$ value is always higher in comparison to those of similarly produced BG and OPS chars. As stated previously, two trends related to the inorganic composition of the samples can be identified. Under the same conditions, feedstocks with inorganic ratio $\mathrm{K} /(\mathrm{Si}+\mathrm{P})$ above 1 follow a catalytic gasification behavior and develop a higher $S_{\mathrm{BET}}$ compared to samples with $\mathrm{K} /(\mathrm{Si}+\mathrm{P})$ below 1 .
Experimental results also showed that chars obtained at burn-off degrees below $30 \%$ are highly microporous, with at least $85 \%$ of their $S_{\mathrm{BET}}$ attributed to micropores. In contrast, for higher burn-off degrees, the microporosity of BG is reduced to $70 \%$, while CS and OPS continue to show micropore percentages above $87 \%$ and $82 \%$, respectively. In fact, BG chars showed a higher development of mesopores with the progress of the gasification process, in comparison to CS and OPS. These differences may be related to the structure of the raw materials and their initial macromolecular composition. In fact, BG is a fibrous grass with high hemicellulose and cellulose content $(>50 \%) .{ }^{41}$ Therefore, the thermal decomposition of these components during the pyrolysis stage may generate a more open char structure, resulting in a higher proportion of mesopores in the char. In contrast, CS and OPS are high-lignin endocarp feedstocks. ${ }^{42,43}$

As reported by Rodriguez-Reinoso, ${ }^{44}$ the pore development process during char gasification begins with the creation of micropores followed by their subsequent widening and then the creation of new pores. In this regard, a less compact structure as in the case of BG facilitates the access of steam into the char structure and the widening of the existing pores, developing mesopores and macropores. Unlike some reported studies that attribute the development of macro- and mesopores to the lignin content of the feedstock, ${ }^{17,35}$ in the present study, the highest development of mesoporosity was observed for the samples with the highest hemicellulose and cellulose content.

In general terms, it can be said that the steam gasification of the analyzed feedstocks produces a highly microporous solid byproduct with surface areas from 500 to $1000 \mathrm{~m}^{2} / \mathrm{g}$, which is close to literature-reported activated carbon values ${ }^{35}$ or values for gasification chars produced under similar conditions. ${ }^{13}$

3.4. Char Surface Oxygen-Containing Functional Groups. The thermal programmed desorption (TPD) analysis

Table 4. Surface and Structure Characteristics of the Analyzed Gasification Chars ${ }^{a}$

\begin{tabular}{|c|c|c|c|c|c|c|c|}
\hline \multirow[b]{2}{*}{ sample } & \multirow{2}{*}{$\frac{\text { char burn-off }}{(\%)}$} & \multicolumn{3}{|c|}{ pore structure } & \multicolumn{3}{|c|}{ TPD $\mathrm{CO}$ and $\mathrm{CO}_{2}$ desorption } \\
\hline & & $S_{\mathrm{BET}}\left(\mathrm{m}^{2} / \mathrm{g}\right)$ & $S_{\text {micro }}\left(\mathrm{m}^{2} / \mathrm{g}\right)$ & $V_{\text {micro }}\left(\mathrm{cm}^{3} / \mathrm{g}\right)$ & $\mathrm{CO}_{2}(\mathrm{mmol} / \mathrm{g})$ & $\mathrm{CO}(\mathrm{mmol} / \mathrm{g})$ & total $(\mathrm{mmol} / \mathrm{g})$ \\
\hline $\mathrm{CS} \_30 \% \_750{ }^{\circ} \mathrm{C} \_1 \mathrm{~h}$ & 14.7 & 631.52 & 550.24 & 0.21 & 0.57 & 0.57 & 1.14 \\
\hline CS_90\%_750 ${ }^{\circ} \mathrm{C} \_1 \mathrm{~h}$ & 25.5 & 725.63 & 603.16 & 0.23 & 0.50 & 0.78 & 1.28 \\
\hline $\mathrm{CS} \_30 \% \_750{ }^{\circ} \mathrm{C} \_2 \mathrm{~h}$ & 28.4 & 772.30 & 684.29 & 0.26 & 0.47 & 0.76 & 1.22 \\
\hline CS_30\%_750 ${ }^{\circ} \mathrm{C} \_3 \mathrm{~h}$ & 43.2 & 884.00 & 779.00 & 0.30 & 0.69 & 1.04 & 1.73 \\
\hline $\mathrm{CS} \_30 \% \_850{ }^{\circ} \mathrm{C} \_1 \mathrm{~h}$ & 57.0 & 1041.83 & 898.90 & 0.34 & 0.84 & 0.57 & 1.41 \\
\hline $\mathrm{CS} \_30 \% \_850{ }^{\circ} \mathrm{C} \_2 \mathrm{~h}$ & 84.6 & 1032.60 & 952.01 & 0.38 & 0.76 & 1.56 & 2.32 \\
\hline BG_30\%_750 ${ }^{\circ} \mathrm{C} \_1 \mathrm{~h}$ & 16.5 & 544.97 & 468.90 & 0.18 & 0.36 & 0.18 & 0.53 \\
\hline BG_90\%_750 ${ }^{\circ} \mathrm{C} \_1 \mathrm{~h}$ & 25.3 & 560.00 & 500.00 & 0.16 & 0.35 & 0.55 & 0.90 \\
\hline BG_30\%_750 ${ }^{\circ} \mathrm{C} \_2 \mathrm{~h}$ & 29.1 & 648.20 & 539.45 & 0.21 & 0.31 & 0.30 & 0.62 \\
\hline BG_30\%_750 ${ }^{\circ} \mathrm{C} \_3 \mathrm{~h}$ & 30.4 & 605.41 & 497.80 & 0.20 & 0.37 & 0.61 & 0.98 \\
\hline BG_30\%_850 ${ }^{\circ} \mathrm{C} \_1 \mathrm{~h}$ & 54.0 & 807.70 & 592.85 & 0.24 & 0.38 & 0.56 & 0.95 \\
\hline $\mathrm{BG} \_30 \% \_850{ }^{\circ} \mathrm{C} \_2 \mathrm{~h}$ & 68.4 & 723.59 & 508.08 & 0.21 & 0.35 & 0.54 & 0.90 \\
\hline BG_30\%_850 ${ }^{\circ} \mathrm{C} \_3 \mathrm{~h}$ & 78.5 & - & - & - & 0.25 & 0.15 & 0.41 \\
\hline OPS_30\%_750 ${ }^{\circ} \overline{\mathrm{C}} \_1 \mathrm{~h}$ & 8.9 & 490.00 & 450.92 & 0.17 & 0.20 & 0.21 & 0.40 \\
\hline OPS_90\%_750 ${ }^{\circ} \mathrm{C} \_1 \mathrm{~h}$ & 15.9 & 553.72 & 479.00 & 0.18 & 0.28 & 0.60 & 0.88 \\
\hline OPS_30\%_750 ${ }^{\circ} \mathrm{C} \_2 \mathrm{~h}$ & 10.8 & 504.20 & 476.40 & 0.18 & 0.23 & 0.45 & 0.68 \\
\hline OPS_30\%_750 ${ }^{\circ} \mathrm{C} \_3 \mathrm{~h}$ & 14.3 & 529.90 & 503.07 & 0.19 & 0.23 & 0.48 & 0.71 \\
\hline OPS_30\%_850 ${ }^{\circ} \mathrm{C} \_1 \mathrm{~h}$ & 27.7 & 667.40 & 550.00 & 0.25 & 0.15 & 0.32 & 0.48 \\
\hline OPS_30\%_850 ${ }^{\circ} \mathrm{C} \_2 \mathrm{~h}$ & 34.5 & 776.00 & 687.67 & 0.26 & 0.17 & 0.33 & 0.50 \\
\hline OPS_30\%_850 ${ }^{\circ} \mathrm{C} \_3 \mathrm{~h}$ & 47.2 & 931.00 & 830.00 & 0.32 & 0.17 & 0.35 & 0.51 \\
\hline OPS_30\%_850 ${ }^{\circ} \mathrm{C} \_4.5 \mathrm{~h}$ & 56.0 & 1014.00 & 883.00 & 0.35 & 0.18 & 0.36 & 0.55 \\
\hline
\end{tabular}

${ }^{a} \mathrm{~N}_{2}$ adsorption test did not yield acceptable results, possibly due to the high ash content of the sample. 
$750^{\circ} \mathrm{C}, 30 \%$ steam, 1 hour

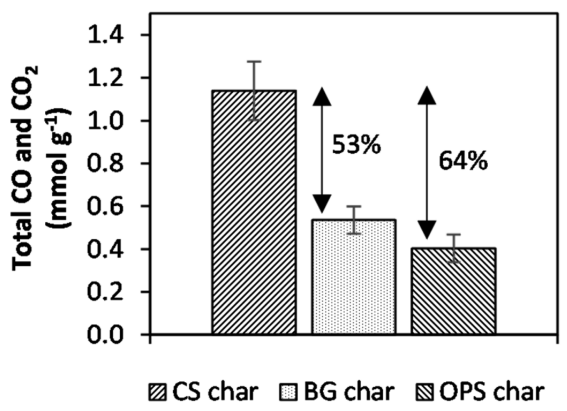

$750^{\circ} \mathrm{C}, 90 \%$ steam, 1 hour



Figure 5. Total $\mathrm{CO}$ and $\mathrm{CO}_{2}$ desorption of gasification chars during TPD analysis.
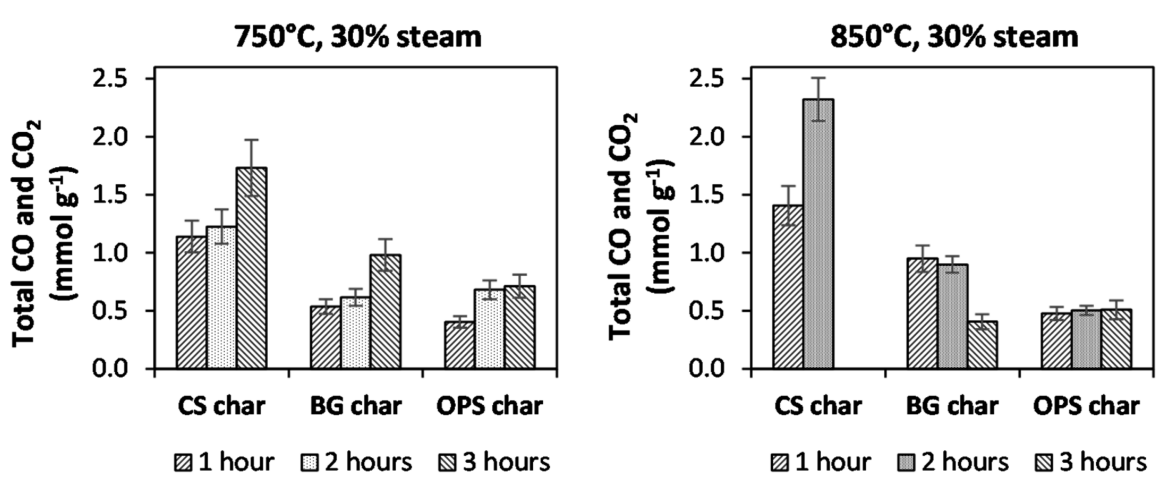

Figure 6. Evolution of total $\mathrm{CO}$ and $\mathrm{CO}_{2}$ desorption with gasification time, during TPD analysis.

of the chars confirmed the existence of a certain amount of oxygen-containing functional groups in their surface (SOFG). For all the tested conditions, the $\mathrm{CO}$ and $\mathrm{CO}_{2}$ desorption of CS chars was higher compared to that of OPS and BG, suggesting the presence of a higher amount of SOFG. This result is consistent with the steam gasification reactivity of the samples, since CS reactivity is considerably higher than OPS and BG. In accordance, under the same conditions, the steam gasification reactions proceed faster, resulting in higher char conversions and activation degrees.

The observed differences between the three char samples were reduced with the increase of the steam percentage in the gasifying agent, as a greater steam quantity was available to react with the carbon matrix. As presented in Figure 5, with $30 \%$ of steam in the gasifying agent, for the BG and OPS chars the $\mathrm{CO}$ and $\mathrm{CO}_{2}$ desorption was 53\% and $64 \%$ lower than that of CS, respectively. In contrast, with $90 \%$ of steam this difference was reduced to $29 \%$ and $31 \%$, respectively.

Even with an increase in the gasification temperature and time, CS chars show a greater amount of SOFG, as seen in Figure 6. At $850{ }^{\circ} \mathrm{C}$, an augmentation in the gasification time from 1 to $2 \mathrm{~h}$ resulted in an increase of $60 \%$ in the $\mathrm{CO}$ and $\mathrm{CO}_{2}$ desorption of CS chars. In contrast, this trend is not observed for BG and OPS. Likewise, for $1 \mathrm{~h}$ gasification, the gas desorption of CS is $30 \%$ and $65 \%$ higher in comparison to BG and OPS, respectively.

As presented in Table 4, for the analyzed chars, the maximum total $\mathrm{CO}$ and $\mathrm{CO}_{2}$ desorption observed was 2.32 and $0.98 \mathrm{mmol} / \mathrm{g}$ for $\mathrm{CS}$ and $\mathrm{BG}$, respectively, at $850{ }^{\circ} \mathrm{C}$ and $30 \%$ of steam in the gasifying agent, and $0.8 \mathrm{mmol} / \mathrm{g}$ for OPS at $750{ }^{\circ} \mathrm{C}$ and $90 \%$ of steam. These values, which are comparable to those of literature-reported activated carbons from lignocellulosic precursors, ${ }^{45,46}$ confirm the potential of steam gasification chars as value-added byproducts for different applications, such as inorganic and organic pollutants adsorption, $^{10,47,48}$ heavy metals removal, ${ }^{49,50}$ gas storage, ${ }^{37,51}$ or soil remediation applications. ${ }^{52,53}$

It is important to note that for the analyzed conditions, even at the same burn-off degree, the observed $\mathrm{CO}$ and $\mathrm{CO}_{2}$ desorption of chars was always in the order $\mathrm{CS}<\mathrm{BG}<$ OPS. This trend is most likely associated with the reactivity of the samples and particularly to the inorganic composition of the raw materials. As discussed earlier, CS is an AAEM-rich feedstock, while the main inorganic constituents of BG and OPS are $\mathrm{Si}$ and P. More precisely, the defined inorganic ratio $\mathrm{K} /(\mathrm{Si}+\mathrm{P})$ of the raw samples is $3.9,0.2$, and 0.17 , respectively, following the order $\mathrm{CS}<\mathrm{BG}<\mathrm{OPS}$.

A detailed analysis of the $\mathrm{CO}$ and $\mathrm{CO}_{2}$ desorption curves showed that the surface of the gasification chars contains an important proportion of acidic SOFG. In particular, the presence of carboxylic acids, peroxides, lactones, and phenols was identified. Furthermore, ether, quinone, and pyrone-like functional groups, reported to have a basic and neutral character, ${ }^{54,55}$ were also observed.

The TPD results regarding the SOFG speciation of the analyzed chars are in accordance with literature-reported characteristics of biochars and activated carbons from lignocellulosic precursors, obtained using TPD or other characterization techniques like FTIR and acid/base titration. In particular, the introduction of acidic groups (e.g., carboxylic acids, phenols, etc.) in the char surface has been associated by several authors to their steam treatment or activation. ${ }^{56-59}$ These characteristics are in line with the gasification conditions, considering that steam was used as the gasifying agent.

In agreement with this, the measured $\mathrm{pH}_{\mathrm{PZC}}$ of all the analyzed samples is in the acidic region, with values between 2 and 3, suggesting the dominance of acidic groups over basic 

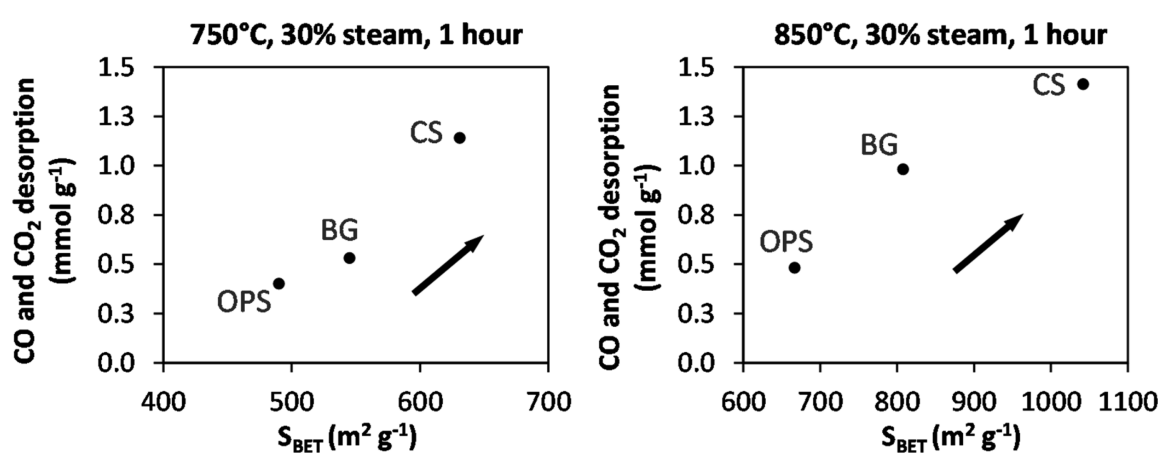

Figure 7. Total $\mathrm{CO}$ and $\mathrm{CO}_{2}$ desorption vs $S_{\mathrm{BET}}$ of chars at the same gasification conditions.

groups in the char surface. ${ }^{60,61}$ No particular trends were observed with the gasification conditions, and no remarkable differences were identified between the three selected precursors. In this regard, as the $\mathrm{pH}_{\mathrm{PZC}}$ represents the $\mathrm{pH}$ value at which the net surface of the char is 0 , the low measured $\mathrm{pH}_{\mathrm{PZC}}$ indicates that steam gasification chars may be suitable for applications where the adsorption or retention of cations is required, such as in heavy metals removal or soil remediation applications. ${ }^{62-64}$

3.5. Relationship between Char Structure and Surface Chemistry. From the experimental results, it was possible to establish a relationship between the char structure and surface chemistry. More specifically, it was noticed that under the same gasification conditions, higher $S_{\mathrm{BET}}$ are also associated with a greater content of SOFG, as presented in Figure 7.

The observed correlation can be explained by the fact that the progress of the steam gasification reactions remove carbon atoms from the char matrix, developing a porous structure and including, at the same time, oxygen-containing surface complexes. $^{37,65}$ Once again, the inorganic composition of the raw biomass could play an important role in the development of SOFG, as it impacts the steam gasification reactivity. The enhanced rate of gasification reactions produced by AAEM and some transition metals may be attributed to the enhanced rate of formation of chemisorbed oxygen in the char matrix. ${ }^{34}$ This could explain the higher $\mathrm{CO}$ and $\mathrm{CO}_{2}$ desorption observed for CS.

In this regard, the inorganic content of the raw biomass impacts not only its gasification rate but also the properties of the gasification solid byproduct. For samples with an inorganic ratio $\mathrm{K} /(\mathrm{Si}+\mathrm{P})$ above 1 , the beneficial impact of AAEM (especially $\mathrm{K}$ ) on the steam gasification reactions resulted also in higher $S_{\mathrm{BET}}$ and SOFG, in comparison to samples with inorganic ratio below 1 .

\section{CONCLUSIONS}

In this work, the influence of the raw biomass characteristics and composition on the physicochemical properties of steam gasification chars is analyzed. Coconut shells (CS), bamboo guadua (BG), and oil palm shells (OPS) were selected as feedstocks, considering their different macromolecular structure and inorganic composition.

The experimental results showed that inorganics have an important impact on the gasification reactivity of the samples and, in consequence, an influence on the porous structure development and surface chemistry of the gasification chars. For samples with inorganic ratio $\mathrm{K} /(\mathrm{Si}+\mathrm{P})$ above 1 , the beneficial impact of AAEM (specially $K$ ) in the steam gasification reactions resulted also in higher surface area development and oxygen-containing functional groups in the char surface, in comparison to samples with inorganic ratio below 1. For its part, the pore size distribution of the chars seems to have a relation with the nature and the macromolecular composition of the raw feedstocks.

The observations and mechanisms presented in this work could be an important reference for real gasification applications working with different kinds of residues, when a simultaneous valorization of the gaseous and solid byproducts is searched. This opens a new approach to properly adapt the gasification parameters and conditions according to the nature and composition of the available feedstocks and according to the required byproducts proportion and characteristics. In relation to gasification chars, the presented results provide a new insight for the engineering of useful value-added materials from agrowastes.

\section{AUTHOR INFORMATION}

\section{Corresponding Author}

*E-mail: 1mromerom@unal.edu.co, lina.romero_millan@ mines-albi.fr. Tel.: +33 (0) 618812544 .

ORCID $\odot$

Lina María Romero Millán: 0000-0001-9049-0362

Notes

The authors declare no competing financial interest.

\section{ACKNOWLEDGMENTS}

The authors gratefully acknowledge COLCIENCIAS for the doctoral scholarship awarded in the frame of the Colombian National Program for Doctoral Formation (647-2014).

\section{REFERENCES}

(1) Terrapon-Pfaff, J.; Dienst, C.; Koenig, J.; Ortiz, W. A CrossSectional Review: Impacts and Sustainability of Small-Scale Renewable Energy Projects in Developing Countries. Renewable Sustainable Energy Rev. 2014, 40, 1-10.

(2) González, A. M.; Sandoval, H.; Acosta, P.; Henao, F. On the Acceptance and Sustainability of Renewable Energy Projects-a Systems Thinking Perspective. Sustainability 2016, 8 (11), 1171.

(3) Basu, P. Gasification Theory. Biomass Gasification, Pyrolysis and Torrefaction 2013, 199-248.

(4) Martínez, J. D.; Mahkamov, K.; Andrade, R. V.; Silva Lora, E. E. Syngas Production in Downdraft Biomass Gasifiers and Its Application Using Internal Combustion Engines. Renewable Energy 2012, 38 (1), 1-9.

(5) Shen, Y. Chars as Carbonaceous Adsorbents/Catalysts for Tar Elimination during Biomass Pyrolysis or Gasi Fi Cation. Renewable Sustainable Energy Rev. 2015, 43, 281-295. 
(6) Wang, D.; Yuan, W.; Ji, W. Char and Char-Supported Nickel Catalysts for Secondary Syngas Cleanup and Conditioning. Appl. Energy 2011, 88 (5), 1656-1663.

(7) Dias, D.; Lapa, N.; Bernardo, M.; Godinho, D.; Fonseca, I.; Miranda, M.; Pinto, F.; Lemos, F. Properties of Chars from the Gasification and Pyrolysis of Rice Waste Streams towards Their Valorisation as Adsorbent Materials. Waste Manage. 2017, 65, 186194.

(8) Hwang, I. H.; Kobayashi, J.; Kawamoto, K. Characterization of Products Obtained from Pyrolysis and Steam Gasification of Wood Waste, RDF, and RPF. Waste Manage. 2014, 34 (2), 402-410.

(9) Guizani, C.; Escudero Sanz, F. J.; Jeguirim, M.; Gadiou, R.; Salvador, S. The Effects of Textural Modifications on Beech WoodChar Gasification Rate under Alternate Atmospheres of $\mathrm{CO} 2$ and H2O. Fuel Process. Technol. 2015, 138, 687-694.

(10) Maneerung, T.; Liew, J.; Dai, Y.; Kawi, S.; Chong, C.; Wang, C.-H. Activated Carbon Derived from Carbon Residue from Biomass Gasification and Its Application for Dye Adsorption: Kinetics, Isotherms and Thermodynamic Studies. Bioresour. Technol. 2016, 200, 350-359.

(11) Benedetti, V.; Patuzzi, F.; Baratieri, M. Gasification Char as a Potential Substitute of Activated Carbon in Adsorption Applications. Energy Procedia 2017, 105, 712-717.

(12) Kilpimaa, S.; Runtti, H.; Kangas, T.; Lassi, U.; Kuokkanen, T. Physical Activation of Carbon Residue from Biomass Gasification: Novel Sorbent for the Removal of Phosphates and Nitrates from Aqueous Solution. J. Ind. Eng. Chem. 2015, 21, 1354-1364.

(13) Klinghoffer, N.; Castaldi, M. J.; Nzihou, A. Catalyst Properties and Catalytic Performance of Char from Biomass Gasification. Ind. Eng. Chem. Res. 2012, 51, 13113-13122.

(14) Hansen, V.; Müller-Stöver, D.; Ahrenfeldt, J.; Holm, J. K.; Henriksen, U. B.; Hauggaard-Nielsen, H. Gasification Biochar as a Valuable By-Product for Carbon Sequestration and Soil Amendment. Biomass Bioenergy 2015, 72 (1), 300-308.

(15) Román, S.; Ledesma, B.; Álvarez-Murillo, A.; Al-Kassir, A.; Yusaf, T. Dependence of the Microporosity of Activated Carbons on the Lignocellulosic Composition of the Precursors. Energies 2017, 10 (4), 542.

(16) Klinghoffer, N. B.; Castaldi, M. J.; Nzihou, A. Influence of Char Composition and Inorganics on Catalytic Activity of Char from Biomass Gasification. Fuel 2015, 157, 37-47.

(17) Daud, W. M. A. W.; Ali, W. S. W. Comparison on Pore Development of Activated Carbon Produced from Palm Shell and Coconut Shell. Bioresour. Technol. 2004, 93 (1), 63-69.

(18) Romero Millán, L. M.; Sierra Vargas, F. E.; Nzihou, A. Steam Gasification Behavior of Tropical Agrowaste: A New Modeling Approach Based on the Inorganic Composition. Fuel 2019, 235, 4553.

(19) Hognon, C.; Dupont, C.; Grateau, M.; Delrue, F. Comparison of Steam Gasification Reactivity of Algal and Lignocellulosic Biomass: Influence of Inorganic Elements. Bioresour. Technol. 2014, 164, 347353.

(20) Perander, M.; Demartini, N.; Brink, A.; Kramb, J.; Karlström, O.; Hemming, J.; Moilanen, A.; Konttinen, J.; Hupa, M. Catalytic Effect of Ca and K on CO 2 Gasification of Spruce Wood Char. Fuel 2015, 150, 464-472.

(21) Kirtania, K.; Axelsson, J.; Matsakas, L.; Christakopoulos, P.; Umeki, K.; Furusjö, E. Kinetic Study of Catalytic Gasification of Wood Char Impregnated with Different Alkali Salts. Energy 2017, 118, 1055-1065.

(22) Romero Millan, L. M.; Sierra Vargas, F. E.; Nzihou, A. Kinetic Analysis of Tropical Lignocellulosic Agrowaste Pyrolysis. BioEnergy Res. 2017, 10 (3), 832-845.

(23) Zhou, J.-H.; Sui, Z.-J.; Zhu, J.; Li, P.; Chen, D.; Dai, Y.-C.; Yuan, W.-K. Characterization of Surface Oxygen Complexes on Carbon Nanofibers by TPD, XPS and FT-IR. Carbon 2007, 45 (4), 785-796.

(24) Ishii, T.; Kyotani, T. Temperature Programmed Desorption. Materials Science and Engineering of Carbon 2016, 287-305.
(25) Bai, Y.; Zhu, S.; Luo, K.; Gao, M.; Yan, L.; Li, F. Coal Char Gasification in $\mathrm{H} 2 \mathrm{O} / \mathrm{CO}$ 2: Release of Alkali and Alkaline Earth Metallic Species and Their Effects on Reactivity. Appl. Therm. Eng. 2017, 112, 156-163.

(26) Asadullah, M.; Zhang, S.; Min, Z.; Yimsiri, P.; Li, C.-Z. Effects of Biomass Char Structure on Its Gasification Reactivity. Bioresour. Technol. 2010, 101, 7935-7943.

(27) Kajita, M.; Kimura, T.; Norinaga, K.; Li, C.-Z.; Hayashi, J.-I. Catalytic and Noncatalytic Mechanisms in Steam Gasification of Char from the Pyrolysis of Biomass. Energy Fuels 2010, 24, 108-116.

(28) Di Blasi, C. Combustion and Gasification Rates of Lignocellulosic Chars. Prog. Energy Combust. Sci. 2009, 35 (2), 121-140.

(29) Dupont, C.; Jacob, S.; Marrakchy, K. O.; Hognon, C.; Grateau, M.; Labalette, F.; Da Silva Perez, D. How Inorganic Elements of Biomass Influence Char Steam Gasification Kinetics. Energy 2016, 109, 430-435.

(30) Umeki, K.; Moilanen, A.; Gómez-Barea, A.; Konttinen, J. A Model of Biomass Char Gasification Describing the Change in Catalytic Activity of Ash. Chem. Eng. J. 2012, 207-208, 616-624.

(31) Zhang, Y.; Ashizawa, M.; Kajitani, S.; Miura, K. Proposal of a Semi-Empirical Kinetic Model to Reconcile with Gasification Reactivity Profiles of Biomass Chars. Fuel 2008, 87, 475-481.

(32) Huang, Y.; Yin, X.; Wu, C.; Wang, C.; Xie, J.; Zhou, Z.; Ma, L.; Li, H. Effects of Metal Catalysts on CO 2 Gasification Reactivity of Biomass Char. Biotechnol. Adv. 2009, 27, 568-572.

(33) Nzihou, A.; Stanmore, B.; Sharrock, P. A Review of Catalysts for the Gasification of Biomass Char, with Some Reference to Coal. Energy 2013, 58, 305-317.

(34) Marsh, H. Activated Carbon, 1st ed.; Elsevier Science: 2006.

(35) Yahya, M. A.; Al-Qodah, Z.; Ngah, C.W. Z. Agricultural BioWaste Materials as Potential Sustainable Precursors Used for Activated Carbon Production: A Review. Renewable Sustainable Energy Rev. 2015, 46, 218-235.

(36) David, E.; Kopac, J. Activated Carbons Derived from Residual Biomass Pyrolysis and Their CO2 Adsorption Capacity. J. Anal. Appl. Pyrolysis 2014, 110, 322-332.

(37) González-García, P. Activated Carbon from Lignocellulosics Precursors: A Review of the Synthesis Methods, Characterization Techniques and Applications. Renewable Sustainable Energy Rev. 2018, 82 (1), 1393-1414.

(38) Paethanom, A.; Yoshikawa, K. Influence of Pyrolysis Temperature on Rice Husk Char Characteristics and Its Tar Adsorption Capability. Energies 2012, 5 (12), 4941-4951.

(39) Cunliffe, A. M.; Williams, P. T. Influence of Process Conditions on the Rate of Activation of Chars Derived from Pyrolysis of Used Tires. Energy Fuels 1999, 13, 166-175.

(40) Rodriguez Correa, C.; Otto, T.; Kruse, A. Influence of the Biomass Components on the Pore Formation of Activated Carbon. Biomass Bioenergy 2017, 97, 53-64.

(41) Zhang, Y.-J.; Xing, Z.-J.; Duan, Z.-K.; Wang, Y.; Li, M. Effects of Steam Activation on the Pore Structure and Surface Chemistry of Activated Carbon Derived from Bamboo Waste. Appl. Surf. Sci. 2014, $315,279-286$

(42) Harman-Ware, A. E.; Crocker, M.; Pace, R. B.; Placido, A.; Morton, S.; DeBolt, S. Characterization of Endocarp Biomass and Extracted Lignin Using Pyrolysis and Spectroscopic Methods. BioEnergy Res. 2015, 8 (1), 350-368.

(43) Mendu, V.; Harman-Ware, A. E.; Crocker, M.; Jae, J.; Stork, J.; Morton, S.; Placido, A.; Huber, G.; Debolt, S. Identification and Thermochemical Analysis of High-Lignin Feedstocks for Biofuel and Biochemical Production. Biotechnol. Biofuels 2011, 4, 43.

(44) Rodriguez-Reinoso, F. Controlled Gasification of Carbon and Pore Structure Development. Fundamental Issues in Control of Carbon Gasification Reactivity 1991, 533-571.

(45) Molina-Sabio, M.; Gonzalez, M. T.; Rodriguez-Reinoso, F.; Sepúlveda-Escribano, A. Effect of Steam and Carbon Dioxide Activation in the Micropore Size Distribution of Activated Carbon. Carbon 1996, 34 (4), 505-509. 
(46) Ghouma, I.; Jeguirim, M.; Dorge, S.; Limousy, L.; Matei Ghimbeu, C.; Ouederni, A. Activated Carbon Prepared by Physical Activation of Olive Stones for the Removal of NO 2 at Ambient Temperature Préparation Par Voie Physique de Carbones Activés Obtenus à Partir de Noyaux d'olives Destinés à l'adsorption de NO 2 a` Température A. C. R. Chim. 2015, 18, 63-74.

(47) Abdel-Fattah, T. M.; Mahmoud, M. E.; Ahmed, S. B.; Huff, M. D.; Lee, J. W.; Kumar, S. Biochar from Woody Biomass for Removing Metal Contaminants and Carbon Sequestration. J. Ind. Eng. Chem. 2015, 22, 103-109.

(48) Hu, X.; Hanaoka, T.; Sakanishi, K.; Shinagawa, T.; Matsui, S.; Tada, M.; Iwasaki, T. Removal of Tar Model Compounds Produced from Biomass Gasification Using Activated Carbons. J. Japan Inst. Energy 2007, 86, 707-7011.

(49) Li, F.; Shen, K.; Long, X.; Wen, J.; Xie, X.; Zeng, X.; Liang, Y.; Wei, Y.; Lin, Z.; Huang, W.; et al. Preparation and Characterization of Biochars from Eichornia Crassipes for Cadmium Removal in Aqueous Solutions. PLoS One 2016, 11 (2), No. e0148132.

(50) Uchimiya, M.; Chang, S.; Klasson, K. T. Screening Biochars for Heavy Metal Retention in Soil: Role of Oxygen Functional Groups. J. Hazard. Mater. 2011, 190, 432-441.

(51) Chen, Y.; Zhu, Y.; Wang, Z.; Li, Y.; Wang, L.; Ding, L.; Gao, X.; Ma, Y.; Guo, Y. Application Studies of Activated Carbon Derived from Rice Husks Produced by Chemical-Thermal Process-A Review. Adv. Colloid Interface Sci. 2011, 163, 39-52.

(52) Borchard, N.; Wolf, A.; Laabs, V.; Aeckersberg, R.; Scherer, H. W.; Moeller, A.; Amelung, W. Physical Activation of Biochar and Its Meaning for Soil Fertility and Nutrient Leaching - a Greenhouse Experiment. Soil Use Manage. 2012, 28 (2), 177-184.

(53) Kołtowski, M.; Hilber, I.; Bucheli, T. D.; Charmas, B.; Skubiszewska-Zieba, J.; Oleszczuk, P. Activated Biochars Reduce the Exposure of Polycyclic Aromatic Hydrocarbons in Industrially Contaminated Soils. Chem. Eng. J. 2017, 310, 33-40.

(54) Montes-Morán, M. A.; Suárez, D.; Menéndez, J. A.; Fuente, E. On the Nature of Basic Sites on Carbon Surfaces: An Overview. Carbon 2004, 42 (7), 1219-1224.

(55) Alves, L. A.; De Castro, A. H.; De Mendonça, F. G.; De Mesquita, J. P. Characterization of Acid Functional Groups of Carbon Dots by Nonlinear Regression Data Fitting of Potentiometric Titration Curves. Appl. Surf. Sci. 2016, 370, 486-495.

(56) Shafeeyan, M. S.; Daud, W. M. A. W.; Houshmand, A.; Shamiri, A. A Review on Surface Modification of Activated Carbon for Carbon Dioxide Adsorption. J. Anal. Appl. Pyrolysis 2010, 89, 143-151.

(57) Bouchelta, C.; Medjram, M. S.; Bertrand, O.; Bellat, J.-P. Preparation and Characterization of Activated Carbon from Date Stones by Physical Activation with Steam. J. Anal. Appl. Pyrolysis 2008, 82 (1), 70-77.

(58) González, P. G.; Pliego-Cuervo, Y. B. Physicochemical and Microtextural Characterization of Activated Carbons Produced from Water Steam Activation of Three Bamboo Species. J. Anal. Appl. Pyrolysis 2013, 99, 32-39.

(59) Arriagada, R.; García, R.; Molina-Sabio, M.; RodriguezReinoso, F. Effect of Steam Activation on the Porosity and Chemical Nature of Activated Carbons from Eucalyptus Globulus and Peach Stones. Microporous Mater. 1997, 8, 123-130.

(60) Gundogdu, A.; Duran, C.; Senturk, H. B.; Soylak, M.; Imamoglu, M.; Onal, Y. Physicochemical Characteristics of a Novel Activated Carbon Produced from Tea Industry Waste. J. Anal. Appl. Pyrolysis 2013, 104, 249-259.

(61) Mahmood, T.; Naeem, A.; Hamayun, M.; Aslam, M.; Ali, R. Potential of Used Camellia Sinensis Leaves as Precursor for Activated Carbon Preparation by Chemical Activation with H3PO4; Optimization Using Response Surface Methodology. Process Saf. Environ. Prot. 2017, 109 (2), 548-563.

(62) Xu, X.; Zhao, Y.; Sima, J.; Zhao, L.; Mašek, O.; Cao, X. Indispensable Role of Biochar-Inherent Mineral Constituents in Its Environmental Applications: A Review. Bioresour. Technol. 2017, 241, 887-899.
(63) Li, H.; Dong, X.; Da Silva, E. B.; De Oliveira, L. M.; Chen, Y.; Ma, L. Q. Mechanisms of Metal Sorption by Biochars: Biochar Characteristics and Modifications. Chemosphere 2017, 178, 466-478.

(64) Cao, X.; Harris, W. Properties of Dairy-Manure-Derived Biochar Pertinent to Its Potential Use in Remediation. Bioresour. Technol. 2010, 101 (14), 5222-5228.

(65) Yahya, M. A.; Al-Qodah, Z.; Ngah, C. W. Z. Agricultural BioWaste Materials as Potential Sustainable Precursors Used for Activated Carbon Production: A Review. Renewable Sustainable Energy Rev. 2015, 46, 218-235. 